\title{
Evaluation of Acorus calamus L. rhizome extract as a bio preservative against wood fungal decay
}

\section{Bandana Dhiman* and Bhupender Dutt}

Department of Forest Products, College of Forestry, Dr. Y.S. Parmar, UHF, Nauni, Solan- 173230 (H.P.), INDIA *Corresponding author. E-mail: bandana.dhiman18@gmail.com

Received: May 20, 2017; Revised received: July 24, 2017; Accepted: January 7, 2018

\begin{abstract}
Wood is most preferred structural material throughout the world and is considered as a complex biological composite with ubiquitous nature. Throughout the world there is an immense pressure on primary durable timbers due to their ever increasing demand. To reduce pressure on the primary species like; Teak, Sal and Deodar etc. one has to look for the other lesser known or secondary species as an alternative. Durability of these species can be enhanced with application of different preservatives and for this one of the best approach is to use herbal based ecofriendly preservatives rather than hazardous chemicals. In this study, the antifungal activity of Acorus calamus rhizome extract was tested on less durable local wood species. The results showed that average growth of Polyporus fungus on taken wood samples were retarded up to $69.44 \%$ after applying $2 \%$ concentration of rhizome extract and act as suitable bio-preservative for non durable wood species.
\end{abstract}

Keywords: Acorus calamus, Biopreservative, Decay resistance, Fungal decay, Rhizome extract

\section{INTRODUCTION}

Total Forest cover in India as per current assessment is $7,01,673 \mathrm{~km}^{2}$ which constitute $21.34 \%$ of the total geographical area of the country whereas annual estimated wood production is 3.175 million $\mathrm{m}^{3}$ (FSI, 2015). Changing needs of the society for multiple forest products to meet out the daily living requirements are driven by social, economic, and environmental factors. Drivers of change in forest products consumption include population and economic growth as well as shifts within forest product demand. To make balance between demand and supply, efforts are being made through various afforestation and plantation programs along with proper post harvest management of forest products. One of the approaches to enhance the durability of wood for its efficient utilization is through 'preservation' (Wegner et al., 2010).

Talking about wood mean imaging a picture of brown solid mass which is obtained from trees and act as prominent constructional material. In scientific term, wood is a hard biological material which is a renewable, biodegradable and sustainable composite of cellulose, hemicelluloses, lignin, extractives and inorganic in a three-dimensional matrix. Two major chemical components in wood are lignin (18-35\%) and carbohydrate $(65-75 \%)$. Both are complex, polymeric materials. Minor amount of extraneous materials, mostly in the form of organic extractives and inorganic material (ash), are also present in wood (4-10\%). Overall, wood has an elemental composition of about $50 \%$ carbon, $6 \%$ hydrogen, $44 \%$ oxygen, and trace amounts of several metal ions (Rowell, 2013).

Wood being a biological material can be readily degraded by bacteria, fungi and termites (Schultz and Nicholas, 2002). Wood extractives have been found to be effective against fungi and insect damage. The attack is usually confined to the sapwood because of the higher extractive content in heartwood and greater natural decay resistance due to presence of phenolic compounds in it. As wood is hygroscopic in nature due to presence of hydroxyl groups which absorb and release water according to changes in the climatic conditions to which they are exposed and become the cause of dimensional instability. The hemicelluloses are mainly responsible for moisture sorption, but the accessible cellulose, noncrystalline cellulose, lignin, and surface of crystalline cellulose also play roles. Also digestion of wood by enzymes initiates at the free hydroxyl sites which is one of the principal reasons why wood is prone to decay (Rowell et al., 2008). However, some wood species are resistant to these degrading agents while others are very susceptible to deterioration (Kityo and Plumptre, 1997). Species which are susceptible must be treated with preservative chemicals to increase their service life and durability.

Primary objective of preservative treatment is to increase the life of material in service, thus decreasing the ultimate cost of the product and avoiding the need of frequent replacement in permanent construction. 
Shortage in supply of durable species becomes the cause of plantation of non-durable species which are more susceptible to wood destroying agencies. Therefore, in order to enhance the service life of non-durable species, preservative treatments become necessary (Tripathi et al., 2009) and is treated with chemical preservatives or synthetic chemical fungicides to prevent damage by these aggressive biodeteriogens (Craig et al., 2001). Chemical wood preservatives such as chromated copper arsenate (CCA) have been banned or limited for some applications in some European countries, the United States and Japan. Now, natural plants extractives to protect wood against wood degrading fungi and insects has been one of the possible approach for developing new wood preservatives (Kartal et al., 2004).

If non durable plant species are treated with herbal preservatives, their use as timber can be enhanced without any harm to environment. Green plants act as a reservoir for inexhaustible source of innocuous fungicides/pesticides, which are mammalian non-toxic and easily biodegradable than synthetic chemicals. To develop eco-friendly wood preservatives, many studies have been conducted. Hence, work objective was proposed to find out the scope of treatment of Acorus calamus L. rhizome extract on wood samples of one coniferous species (Pinus roxburghii Sargent) and another two broad leaved species (Celtis australis and Bombax ceiba L.) of Himachal Pradesh.

\section{MATERIALS AND METHODS}

About species: Pinus roxburghii belongs to family coniferae which is main resin-producing pine of India having resin ducts in it. Celtis australis L. belongs to family Ulmaceae which is highly susceptible to attack by decay and staining fungi as well as insect damage. Bombax ceiba L. belongs to family Bombacaceae and its wood is liable to rapid decay due to fungus and insect attack.

About extract source: Acorus calamus is a plant of perennial wetland monocot of Acoraceae family and is commonly known as "bach" or "ugragandha" in India, Sweet flag in English. Roots, rhizomes and leaves have been used in the Indian systems of traditional medicine for hundreds of years. This plant has insecticidal properties (Perrett, Sheena and Whit field, 1995).

Preparation of wood samples: Wood samples of $\mathrm{Pi}$ nus roxburghii Sargent, Celtis australis L. and Bombax ceiba L. of size $5 \mathrm{~cm} \times 2.5 \mathrm{~cm} \times 2.5 \mathrm{~cm}$ (longitudinally x radially $\mathrm{x}$ tangentially) were acquired from the local carpenter. These samples were properly planed and sanded to remove loosely adhering fibres on their surface.

Preparation of rhizome extract and samples treatment: Autumn is the best season for extraction of calamus rhizhomes from field. Wash the rhizhomes with water to remove the mud and allowed to dry in the open under shade for one day. Cut the rhizome into small slices and chipped material allowed to complete dry and then finely powdered with the help of grinder and further dried in the oven for $24 \mathrm{hrs}$ at $50^{\circ}+1^{\circ} \mathrm{C}$. The powdered material was extracted with methanol in soxhlet apparatus on a boiling water bath at $60-70^{\circ} \mathrm{C}$. Extracted material of sweet flag does not fully dry as it contain oil. Then 2.5 litres stock solution of 10 per cent concentration is prepared by with mixing 5\% methanol. From this $10 \%$ conc. stock solution different conc. solutions were made i.e., $0.25 \%, 0.50 \%, 1 \%, 1.50 \%$ and $2 \%$ for treatment. From the prepared 10 per cent stock solution, different concentrations for dip treatment were prepared. The wood specimens of Pinus roxburghii Sargent, Celtis australis L. and Bombax ceiba L. were dipped in $0.25 \%, 0.5 \%, 1 \%, 1.5 \%$ and 2 $\%$ (w/v) Acorus calamus L. extract solution for 72 hours. The samples meant for control were dipped in distilled water. After dipping treatment specimens were first dried in air and then dried at $105-+2{ }^{\circ} \mathrm{C}$ in oven up to constant weight.

Isolation and culture of fungus on treated wood samples for test: An isolated pure culture of Polyporus fungus was revived in Plant Pathology Lab and transferred to the agar slant which was purified by hyphal tip technique. The purified fungal culture was again transferred to Petri plates containing malt agar medium and kept for incubation at $25+1{ }^{\circ} \mathrm{C}$ for routine work. For the growth of fungus, malt agar solid media was prepared directly by adding 2 per cent of malt and 2 per cent of agar in $1000 \mathrm{ml}$ distilled water. About $100 \mathrm{ml}$ of the medium was poured in glass jars of 500 $\mathrm{ml}$ and autoclaved at $15 \mathrm{lb}$ pressure per square inch (psi) for 20 minutes at $121^{\circ} \mathrm{C}$. Each treatment was replicated three times aseptically and allowed to solidify. The glass jars were inoculated with culture bits $(5 \mathrm{~mm})$ cut from 10 days old vigorously growing culture and the inoculated glass jars were incubated at $25+1{ }^{\circ} \mathrm{C}$. Wood samples were sterilized by keeping them under UV light in Laminar Air Flow (LAF) for 20 minutes prior to fungus decay tests. All instruments used under LAF were sterilized with alcohol then with spirit lamp to avoid contamination and for better results. Inspection and evaluation of fungus colonization on wood was made by visual assessments after one month.

Observations recorded: The following observations were recorded to study the effect of extract on growth of fungus:

Disease severity: The following scale was used for recording the disease severity:

\begin{tabular}{|c|c|c|}
\hline $\begin{array}{l}\text { Numerical } \\
\text { ratings }\end{array}$ & $\begin{array}{l}\text { \% fungus coloniza- } \\
\text { tion on surface }\end{array}$ & Description \\
\hline 0 & 0 & No surface coverage \\
\hline 1 & $0-25$ & $\begin{array}{l}\text { Very less surface } \\
\text { coverage }\end{array}$ \\
\hline 2 & $26-50$ & $\begin{array}{l}\text { Less surface cover- } \\
\text { age }\end{array}$ \\
\hline 3 & $51-75$ & $\begin{array}{l}\text { Moderate surface } \\
\text { coverage }\end{array}$ \\
\hline 4 & $>76$ & $\begin{array}{l}\text { Large surface cover- } \\
\text { age }\end{array}$ \\
\hline
\end{tabular}


Table 1. Percent variation of $A$. calamus L. rhizome extract on fungus growth inhibition.

\begin{tabular}{|c|c|c|c|c|}
\hline \multirow[b]{2}{*}{ Treatment } & \multicolumn{4}{|c|}{ Species } \\
\hline & $\begin{array}{c}\text { Pinus roxburghii Sargent } \\
\left(\mathrm{S}_{1}\right)\end{array}$ & $\begin{array}{c}\text { Celtis australis } \mathbf{L} . \\
\left(\mathbf{S}_{2}\right)\end{array}$ & Bombax ceiba L. $\left(\mathrm{S}_{3}\right)$ & Mean \\
\hline$T_{1}(0.25 \%)$ & $16.67(20)$ & $0.00(0)$ & $8.33(10)$ & $8.33(10)$ \\
\hline$T_{2}(0.50 \%)$ & $25.00(30)$ & $8.33(10)$ & $16.67(20)$ & $16.67(20)$ \\
\hline$T_{3}(1.00 \%)$ & $41.67(40)$ & $25.00(25)$ & $25.00(30)$ & $30.56(32)$ \\
\hline$T_{4}(1.50 \%)$ & $50.00(45)$ & $33.33(35)$ & $58.33(50)$ & $47.22(43)$ \\
\hline $\mathrm{T}_{5}(2.00 \%)$ & $75.00(60)$ & $66.67(55)$ & $66.67(55)$ & $69.44(57)$ \\
\hline$T_{6}$ (Control) & $0.00(0)$ & $0.00(0)$ & $0.00(0)$ & $0.00(0)$ \\
\hline Mean & $34.72(32)$ & $22.22(21)$ & $29.17(27)$ & \\
\hline
\end{tabular}

*Values in parenthesis are arc sine transformed values.

\begin{tabular}{lr}
\hline $\mathbf{C D}_{\mathbf{0} 0 \mathbf{5}}$ & \\
\hline CD Species & 7.05 \\
CD Treatment & 9.98 \\
CD Species $\times$ Treatment & NS \\
\hline
\end{tabular}

Per cent Disease severity on surface was calculated according to McKinney (1923).

Disease severity $=$ Sum of all disease rating/Total number of rating $\mathrm{x}$ Maximum disease grade $\mathrm{x} 100$

Per cent growth inhibition (I): Per cent growth inhibition (Vincent, 1947) was calculated as:

I $=\mathrm{C}-\mathrm{T} / \mathrm{C} \times 100$

.....eqn $(2)$

Where,

I $=$ Per cent growth inhibition

$\mathrm{C}=$ Per cent fungus colonization in control

$\mathrm{T}=$ =Per cent fungus colonization in treated wood

Statistical analysis: All the data obtained were subjected to an analysis of variance and statement of significance are based on $\mathrm{P} \leq 0.05$ (Gomez and Gomez, 1984).

\section{RESULTS AND DISCUSSION}

Results pertaining to per cent growth inhibition are presented in Table 1, which revealed significant values in different species and treatments. Among specie the maximum 34.72 per cent growth inhibition was visually observed in Pinus roxburghii Sargent and minimum 22.22 per cent inhibition was in Celtis australis L. Among the treatments highest value of 69.44 per cent was recorded in $\mathrm{T}_{5}$ at 2 per cent concentration of $\mathrm{Aco}$ rus calamus $\mathrm{L}$. rhizome extract and the lowest value of 8.33 per was noticed in $\mathrm{T}_{1}$ at 0.25 per cent concentration with $0 \%$ inhibition in water treatment in $\mathrm{T}_{6}$ (control). Species and treatments interactions were found to be non-significant at 5 per cent level of significance. Polyporus fungus colonization on wood samples has been found to decrease with increase in $A$. calamus L. rhizome extract concentration i.e. at 2.00 per cent concentration minimum fungus colonization was observed as compared to 0.25 per cent concentration. The most important characteristic component in essential oil Acorus calamus is beta-asarone (Raina et al. 2003). The compound $\beta$-asarone $[(\mathrm{Z})-1,2$ trimethoxy-5-prop-1-enyl-benzene] is of moderate acute toxicity. Beta-asarone in A. calamus rhizome was demonstrated to have antibacterial activity (McGraw et al. 2002). One of the methanol extract of Acorus calamus containing $\beta$-asarone fraction showed high antifungal activity against Microsporum gypseum, Trichophyton rubrum (Vohora et al., 1990 \& Mukherjee et al. 2007).

Similar findings were reported by Astiti and Suprapta (2012) while analysing methanol extract of Teak leaf, which significantly inhibited the fungal radial growth with concentrations $0.5 \%, 1 \%, 2 \%$ and $4 \%(\mathrm{w} / \mathrm{v})$, found to be decreases with increase in concentration and can thus be considered as one of the alternatives to chemical wood preservatives for controlling the wood decay in Albizia falcataria.

According to Ssemaganda et al., (2011) untreated samples of Eucalyptus grandis were attacked by termites in the first month of establishment of the experiment; while Neem extracts preserve the treated wood samples. Devi (2013) and Chauhan (2013) have also observed that at 2.00 per cent concentrations of Ageratum conyzoides L. and Melia azedarach L. extract have minimum fungus colonization in wood and proved to be a good biopreservative. Similar results have been obtained in a study where both methanolic and ethanolic extracts of Neem leaves were able to inhibit the growth of the test fungus at a concentration of 3.0 per cent as compared to acetone extract. The 3.0 per cent concentration of ethanolic extract showed the best performance against the test on various wood decaying fungi (Kabir and Alam, 2007) and also found similar results by using the leaf extract of Dalbergia sissoo. It has been also reported that the antifungal properties of poisonous plant extract from Nerium oleander L. can make it effective wood preservative (Goktas et al., 2007). Natural products from plants such as Ageratum conyzoides, Ficus retusa, Lavandula pubescens, Lawsonia alba etc. have been evaluated and found to have great potentials as novel fungicide sources for controlling pathogenic fungi (Bazaid et al., 2010).

\section{Conclusion}


It was observed that with increase in concentration of A. calamus rhizome extract from $0.25 \%, 0.50 \%, 1 \%$, $1.50 \%$ and $2 \%$, growth of Polyporus fungus on wood samples decrease sequentially. Among the treatments maximum inhibition mean value of 69.44 per cent was recorded in $\mathrm{T}_{5}$ at 2 per cent concentration and the lowest value of 8.33 per in $\mathrm{T}_{1}$ at 0.25 per cent concentration with $0 \%$ inhibition in water treatment in $\mathrm{T}_{6}$ (control). It can be concluded from the present work that the rhizome extract from $A$. calamus L. have positive effect on non durable wood species for increasing their life span and durability. As biological damage to wood and wood products is mainly caused by the mould, stain, decay fungi, beetles and termites etc. and to reduce their impact, development of ecofriendly herbal plants extracts is one of the vital discovery for wood protection and preservation industries without affecting environment. Further study is needed to isolate and identify the active compounds in A. calamus rhizhome that are responsible for antifungal activity against wood decay fungi.

\section{REFERENCES}

Astiti, N.P.A and Suprapta, D.N. (2012). Antifungal activity of teak (Tectona grandis) leaf extract against arthrinium phaeospermum (Corda), the cause of wood decay on albizia falcataria (L.) Fosberg. ISSAAS Philippines. 18 (1): 62-69.

Bazaid, S.A. and Nehal, S.E. 2010. Assessment of the Bioregulatory Activity of the Leaf Juices of Higher Plants in Al-Taif, Saudi Arabia against Fusarium solani, Phytopthora spp. and Rhizoctonia solani. Archives of Phytopathology and Plant Protection. 43(11): 1064-1071.

Chauhan, K. (2013). Studies on wood characteristics using Melia azedarach $\mathrm{L}$ leaves extract as a wood biopreservative. M.Sc. Thesis, Dr. Y. S. Parmar University of Horticulture and Forestry, Nauni (Solan) 74 p.

Craig, J.B., Rodney, A.E. and Thorp, C.H. (2001). Effects of chromated copper arsenate (CCA) wood preservative on early fouling community formation. Marine Pollution Bulletin. 42 (11): 1103-1113.

Devi, N. (2013). Studies on wood characteristics using Ageratum conyzoides L. extract as a wood biopreservative. M.Sc. Thesis, Dr .Y. S. Parmar University of Horticulture and Forestry, Nauni (Solan) $77 \mathrm{p}$.

FSI, 2015 - www.fsi.nic.in

Gomez, K. A. and Gomez, A. A. (1984). Statistical procedures for agricultural research. John Wiley and sons, New Delhi, $680 \mathrm{p}$

Goktas, O., Mammadov, R., Baysal, E., Duru, M.E., Ozen, E. and Colak, A.M. (2007). Application of extracts from poisonous plant, Nerium oleander L. as a wood preservative. African Journal of Biotechecnology. 6 (17): 2003-2003.

Kartal, S.N., Dorau, B.F., Lebow, S.T. and Green, F. (2004).
Effects of inorganic ions on leachability of wood preserving N, N-hydroxynaphthalaiflide (NHA). Forest Product Journal. 54: 80-84.

McGraw, L.J., Jager, A.K. and Van Staden, J. (2002). Isolation of $\beta$-asarone, an antibacterial compound from Acorus calamus in South Africa. South African Journal of Botany. 68: 31-35.

Mukherjee, P.K., Kumar, V. and Houghton, P.J. (2007). In vitro acetyl cholinesterase inhibitory activity of essential oil from Acorus calamus and its main constituents. Planta Medica. 73(3): 283-285.

McKinney. H.H. (1923). Influence of soil temperature and moisture on infection of wheat seedlings by Helminthosporium sativum. Journal of Agriculture Research. 26: 195-217.

Parrett, Sheena, and Whit field. (1995). Antihelminthic and pesticidal activity of Acorus. Annal of Plant Protection Sciences. 20(2): 452p.

Kabir, A.H. and Alam, M.F. (2007). Reduction of Environmental Toxicity Through Eco-friendly Wood Biopreservative. International Research Group on Wood Preservation. IRG/WP: 07-50243.

Kityo, P.W. and Plumptre R.A. (1997). The Uganda Timbers users Handbook. A guide to better timber use. Common Wealth Secretariat, London.

Raina, V.K., Srivastava, S.K. and Syamasunder, K.V. (2003). Essential oil composition of Acorus calamus L. from the lower region of the Himalayas. Flavour and Fragrance Journal. 18: 18-20.

Rowell, R.M., Kattenbroek, B., Ratering, P., Bongers, F., Leicher, F. and Stebbins, H. (2008). Production of Dimensionally Stable and Decay Resistant Wood Components Based on Acetylation. Presented at International Conference on Durability of Building Materials and Components, Istanbul, Turkey.

Rowell, R.M. (2013). Handbook of wood chemistry and wood composites. $2^{\text {nd }}$ ed. CRC Press. Boca Raton; London; New York. 687p.

Schultz, T.P. and Nicholas, D.D. (2002). Development of Environmentally-benign Wood Preservatives based on the Combination of Organic Biocides with Antioxidants and Metal chelators. Phytochemistry. (61): 555-560.

Ssemaganda I.E., Mugabi, P. and Tumwebaze, S.B. (2011). Effectiveness of selected preservatives in Protecting ugandan grown Eucalyptus grandis wood Against termite attack. Maderas. Ciencia y Tecnología. 13(2): 135-142.

Tripathi, S., Rawat, K., Dhayani, S. and Pant, H. (2009). Potential of Lantana camara L. weed against wood destroying fungi. The Indian forester. 135(3): 403-411.

Vincent, J.M. (1947). Distortion of fungal hyphae in the presence of certain inhibitors. Nature. 150: 850p.

Vohra, S. B., Shah, S. A. and Dandia, P. C. (1990). Central nervous system studies on an ethanol extracts of Acorus calamus rhizomes. Journal of Ethnopharmacology. 28: 53-62.

Wegner, T., Skog, E., Ince, P. J. and Michler, C. J. (2010). Uses and Desirable Properties of Wood in the 21st Century. Journal of Forestry. 165-173pp. 